Ryszarda BULAS

(Lublin, KUL)

\title{
IRLANDIA A BIZANCJUM. IKONOGRAFIA, ,TRZECH HEBRAJCZYKÓW W PIECU OGNISTYM" NA KRZYŻACH CELTYCKICH
}

Temat relacji między sztuką wczesnośredniowiecznej Irlandii a bizantyjskim Wschodem nie pojawił się dotąd w literaturze przedmiotu, choć tu i ówdzie spotkamy sugestie o możliwości takowych związków ${ }^{1}$. Niniejszym artykułem chciałabym rozpocząć cykl prac ukazujących dużą rolę chrześcijańskiego Wschodu nie tylko, jak ukazało to już wiele publikacji, w kwestii inspiracji monastycyzmem egipskim i syryjskim w Irlandii ${ }^{2}$, ale także w dziedzinie artystycznej. Dla potrzeb artykułu należy uściślić pojęcie „bizantyjskości” w sztuce. Rozumiem je nie tylko w kontekście tradycji artystycznej, która ukształtowała się na terenach Cesarstwa Bizantyjskiego, ale także na terenach będących pod jego kulturowym wpływem. Siła tej tradycji była duża i trwała na obszarze od Grecji i Bałkan do Egiptu, Syrii, Palestyny, Armenii i Rosji. To na tych terenach, na przestrzeni od V do XV wieku, kwitła w wielu ośrodkach sztuka o charakterze bizantyjskim także w czasach, kiedy Bizancjum ograniczało się tylko do części Anatolii i zachodnich wybrzeży Grecji. Charakter tej sztuki okazał się być nieśmiertelny, bowiem nawet kiedy Cesarstwo Bizantyjskie znikło z mapy Europy, jej przejawy trwały nadal na terenach Rosji i Europy Wschodniej do XIX wieku, a w pewnym stopniu trwają tam nadal do dziś 3 .

Bizantyjskość w sztuce oznacza swoistą mentalność, sposób myślenia czy postrzegania rzeczywistości. Artyście bizantyjskiemu bardziej zależało na wy-

${ }^{1}$ Bizantyjskie inspiracje wielu scen biblijnych w sztuce Irlandii sugerują: F. Henry, Irish art during the Viking Invasions (800-1020 A.D.), London 1967, 78- 81. H. Richardson, Jewelled Cross and its canopy, w: From the Isles of the North. Early medieval art in Ireland and Britain, ed. C. Bourke, Belfast 1995, 177-186. Na koptyjskie i nubijskie inspiracje wskazują M. Werner, The Madonna and Child Miniature in the Book of Kells, part I-II, ,The Art Bulletin” 54 (1972) 2-13, 129-139; P.O. Scholz, Christlicher Orient und Irland, w: Nubia et Oriens Christianus. Festschrift für C. Detlef G. Müller zum 60. Geburtstag, ed. P.O. Scholz - R. Stempel, Köln 1987, 387-443.

${ }^{2}$ Por. m.in. N.K. Chadwick, The Age of the Early Celtic Church, London 1961, 1-118; J.N. Hillgarth, The East, Visigothic Spain and the Irish, StPatr 4 (1961) 442-456.

${ }^{3}$ O wpływach sztuki bizantyjskiej na terenach euroazjatyckich por. R.N. Frye, Byzantine and Sasanian trade relations with northeastern Russia, DOP 26 (1972) 263-269; G. Varnadsky, The Eurasian Nomads and their Art in the history of civilization, ,Saeculum" 1 (1950) 74-86. 
rażeniu ukrytej wiedzy o świecie, niż na dobrym kopiowaniu jego widzialnego oblicza. Jest to sztuka bardziej symboliczna niż wyobrażeniowa, bardziej metaforyczna niż realistyczna. Ważną cechą tej sztuki jest jej „mityczność”. Oznacza ona umiejętność dostrzegania w rzeczywistości odbicia stałych paradygmatów, powtarzających się wzorców, rytmicznych akcentów, które mają oznaczać nieustającą, ciągle się odnawiającą boską kreację w świecie widzialnym. Wiele elementów podobnego podejścia do sztuki dostrzegam w mentalności irlandzkich artystów wczesnego średniowiecza. Znalazły one wyraz w kopiowaniu wschodnich schematów ikonograficznych i kompozycji przedstawień. Odbicie tych wzorców znajdziemy na przestrzeni setek lat, nie tylko w sztuce, która była pod wpływem sztuki bizantyjskiej na chrześcijańskim Wschodzie, ale także na Wyspach Brytyjskich. Sporadyczne wpływy wschodnie, wynikające z handlu, pielgrzymek i relacji politycznych, dostrzegamy w sztuce całej Europy zachodniej ${ }^{4}$.

Motyw „Trzech Hebrajczyków w piecu ognistym” znajdziemy w trzech kręgach kulturowych: sztuce wczesnochrześcijańskiej, na irlandzkich krzyżach oraz w sztuce chrześcijańskiego Wschodu. Zebrane przykłady wydają się wyraźnie grupować w trzy typy ikonograficzne, które określam jako: rzymski, koptyjsko-nubijski i bizantyjsko-irlandzki. A. Walton zauważa, że kompozycja omawianej sceny ewoluuje w czasie od linearnej do piramidalnej ${ }^{5}$. Dwa pierwsze wyróżnione przeze mnie typy mają rzeczywiście charakter linearny (horyzontalne ustawienie młodzieńców i całej sceny). Typ trzeci ma charakter piramidalny (środkowy młodzieniec jest zwykle większy a całość piramidalnie wieńczy wielka postać anioła). Przykłady zebrane do analizy, reprezentujące typ rzymski (od. końca III do pocz. V wieku), pochodzą ze ścian katakumb, sarkofagów, mozaik, terakotowych lampek, szkła zdobionego, wyrobów metalowych oraz z kości słoniowej. A. Carletti zebrał i skatalogował 214 takich przykładów 6 .

${ }^{4}$ Por. J. Ebersolt. Orient and Occident. Recherches sur les influences byzantines et orientales en France avant et pendant les Croisades, Paris 1954; K. Weitzmann, Art in the Medieval West and its contacts with Byzantium, London 1982; Byzatine East, Latin West. Art-Historical Studies in Honor of Kurt Weitzmann, ed. Ch. Moss - K. Kiefer, New Jersey 1995; A. Grabar Le rayonnement de l'art. Sassanide dans monde chrétien, w: Atti del convegno internationale sul tema: La Persia nel Medioevo (Roma, 31 III - 5 IV 1970), Roma 1971, 503-515.

${ }^{5}$ Por. A. Walton, The Three Hebrew Children in the Fiery Furnace. A Study in Christian Iconography, w: Medieval Mediterranean: Crosscultural Contacts, ed. M.J. Chiat - K.L. Reyerson. St. Cloud Minn. 1988, 57, cyt. za. M. Łaptaś - S. Jakobielski, , Unknown” mural of the three youths in a fiery furnace from the Faras cathedral, w: Ars Greca, Ars Latina, red. W. Bałus W. Ceran - O. Jurewicz i in., Kraków 2001, 79.

${ }^{6}$ Por. C. Carletti, I tre giovani ebrei di Babilonia nell'arte cristiana antica, Brescia 1975, 119 . 157; zob. też. M. Rassart-Debergh, Les trois Hébreux dans l'art paléochrétien iconographie, „Byzantion” 48 (1978) 430-455; B. Wronikowska, Picturae sacrae. Motywy ikonograficzne malowideł przedkonstantyńskich w chrześcijańskich katakumbach Rzymu, Lublin 1990, 152-154; DACL VI/2 2107-2126; B. Filarska, Początki sztuki chrześcijańskiej, Lublin 1986, 158-159. 
Typ koptyjsko-nubijski (V-XI wiek) reprezentują malowidła z mauzoleum w ElBagawat, koptyjskiego klasztoru w Wadi Sarga (Tebaida) oraz kościołów nubijskich, głównie katedry z Faras ${ }^{7}$. Typ bizantyjsko-irlandzki pojawia się nie wcześniej niż w IX wieku, a przykłady pochodzą z Psałterza Chludowa, bizantyjskiego manuskryptu homilii Grzegorza z Nazjanzu, palestyńskiego manuskryptu Sacra Parallela, manuskryptu z klasztoru na Górze Athos oraz wielu irlandzkich krzyży ${ }^{8}$. Wiemy z przekazu J. Wilperta, że scena taka znajdowała się także na ścianach kościoła Santa Maria Antiqua w Rzymie, a datowana była na VII wiek ${ }^{9}$; zły stan zachowania malowidła nie pozwala jednak opisać i przeanalizować tego przedstawienia.

Przekaz biblijny pochodzący z Księgi Daniela (3,19-24) opisujący męczeństwo trzech młodzieńców z rozkazu Nabuchodonozora podaje fakty, które powinny znaleźć się w sztuce: trzech młodzieńców stojących w ogniu pieca, rozpalony piec, mężczyźni wrzucający drwa do pieca (brak danych, ilu ich było) i Nabuchodonozor. Gdy przyjrzymy się wszystkim zebranym przedstawieniom pod kątem ich wierności z przekazem biblijnym, okaże się, że dopiero późne bizantyjskie ikony (XIV w.) są całkowicie wierne wobec Biblii. Wcześniejsze, opisywane tu przykłady, mniej lub bardziej odchodzą od tekstu źródłowego (brak Nabuchodonozora, brak postaci wykonujących jego rozkaz) lub dodają elementy nieistniejące w tekście biblijnym (Bóg Ojciec, gołąb, anioł).

Ilustracja historii z Księgi Daniela pojawia się w sztuce chrześcijańskiej już w końcu III wieku. C. Carletti, autor monografii poświęconej Trzem Hebrajczykom w sztuce wczesnochrześcijańskiej, wskazuje na ścianach katakumb 20 takich scen (zob. il. 1) na sarkofagach az 57 (il. 2-4), na lampkach 11 (il. 5) oraz na 22 przedmiotach rzemiosła (kość słoniowa, wyroby metalowe, szkło). Przedstawienia tam ukazane tworzą stały typ ikonograficzny: trzej młodzieńcy w strojach orientalnych stoją horyzontalnie ustawieni, $\mathrm{z}$ uniesionymi ramionami, wśród płomieni sięgających kolan lub na murowanym piecu, z którego wydobywają się płomienie. Zwykle scenie tej towarzyszą jeden lub dwa gołę$b_{i}{ }^{10}$. Na sarkofagach często obok omawianej sceny widnieje Arka z Noem i gołębicą, natomiast wśród młodzieńców stoi jeszcze jedna postać (m.in. na sarkofagu watykańskim, sarkofagu Marci Roman Celsa) utożsamiana z Bogiem Ojcem (ma brodę i kręcone włosy) ${ }^{11}$. Czasami obok pieca stoi postać dorzucająca do pieca (il. 3-4). Zaledwie na czterech z 214 przykładów pojawia się

${ }^{7}$ Por. K. Wessel, L'art copte. L'art antique de la Basse-époque en Égypte, Bruxelles 1964, $174-175$

${ }^{8}$ Wszystkie te paralele wskazuje P. Harbison, The High Crosses of Ireland. An Iconographical and Photographic survey, I, Bonn 1992, 226.

9 Por. J. Wilpert, Die Römischen Mosaiken und Malereien der Bauten vom bis 13. Jahrhundert, I-IV, Freiburg 1916, tab. 146.

${ }^{10}$ Por. Wronikowska, Picturae sacrae, s. 152.

11 Por. DACL VI/2 2120. 
wśród młodzieńców postać anioła (są to 3 lampki, które pochodzą z płn. Afryki i Syrakuz). Motyw męczeństwa młodzieńców omawiają m.in. Klemens Rzymski, Tertulian, Orygenes i Hipolit widząc w niej symbol opiekuńczej roli Boga wobec tych, co wielbią Jego imię i są wzorem wiary ${ }^{12}$. Natomiast badacze sztuki wczesnochrześcijańskiej widzą w niej obraz zmarłego, chronionego przez Boga przed ogniem piekielnym (H. Leclercq), nadziei na zbawienie wieczne (C. Carletti), wyraz idei ocalenia i symbol ofiar ocalenia wiązany z kultem męczenników (m.in. J. Wilpert) ${ }^{13}$. Omówione wyżej przykłady tworzą tzw. typ rzymski: generalnie nie występuje w nim postać anioła, nieliczne przykłady związane są z Afryką (Kartagina, Hippona).

Typ koptyjsko-nubijski wydaje się mieć swe początki w IV/V-wiecznych lampkach oliwnych północnej Afryki, a jego cechą charakterystyczną jest obecność anioła. Jest on tu równy młodzieńcom, natomiast od X wieku ma on ogromne rozmiary, co będzie stałą cechą sztuki chrześcijańskiego Wschodu. Jednak scena inaczej jest zaaranżowana w sztuce północnej Afryki, a inaczej w sztuce średniowiecza bizantyjskiego. W sztuce Koptów i sztuce Nubii występuje anioł pomiędzy młodzieńcami w taki sposób, że dwóch ma po swej jednej stronie, a jednego po drugiej. Ten nowy element ikonografii pojawia się na sklepieniu kopuły mauzoleum Exodusu w El Bagawat z IV/V wieku (il. 6) oraz na malowidle $z$ Wadi Sarga z V/VI wieku (il. 7). Taki typ kompozycji rozwinął się w malarstwie Nubii chrześcijańskiej w okresie VIII-XI wieku (il. 8 i 9) ${ }^{14}$. Stwierdza się istnienie w Nubii około dziesięciu przedstawień z młodzieńcami w ogniu; trzy z nich pochodzą z katedry w Faras. W przykładach tych wzrasta rola anioła, i nie tylko stoi on pomiędzy młodzieńcami, ale wydaje się tam pełnić kluczową rolę dzięki wielkim skrzydłom, którymi przykrywa trzech młodzieńców niczym parasolem (pod jednym skrzydłem trzyma dwóch, pod drugim jednego). Ten typ przedstawienia pojawia się dopiero $\mathrm{w} \mathrm{X}$ wieku, bowiem przykład VIII-wieczny z Faras pokazuje jeszcze anioła ze skrzydłami złożonymi ${ }^{15}$. Ponieważ obecność anioła jest później stałą cechą przedstawień bizantyjskich, omówione przykłady mogą wskazywać na to, że typ ikonograficzny $\mathrm{z}$ aniołem powstał w chrześcijańskiej sztuce Afryki północnej bądź w sztuce koptyjskiej.

Nubijski typ z rozłożonymi skrzydłami anielskimi ma elementy wspólne z następną grupą przedstawień, bizantyjsko-irlandzką, gdzie anioł także pełni główną rolę, ale inaczej wkomponowano go w scenę. Irlandzkie przykłady

12 Cyt za: Wronikowska, Picturae sacrae, s. 152-153, oraz przypisy 379-385.

13 Cyt. za: Wronikowska, Picturae sacrae, s. 153-154.

14 Por. M. Rassart, Les trois Hebreux dans la Furnaise en Égypte et en Nubie chrétienne. Studi di onore di Uga Manneret de Villard, I: La valle del Nila in epoca Cristiana = „Rivista degli Studi Orientali” 58 (1987) 141-145; Wessel, L'art copte, s. 174; Łaptaś - Jakobielski, , Unknown” mural of the three youths, s. 75-85.

15 Malowidło nr 80, por. Łaptaś - Jakobielski, „Unknown” mural of the three youths, s. 83. 
„Młodzieńców w piecu ognistym” pochodzą z IX i X wieku i tworzą nowy typ ikonograficzny. Typ ten łączy ze sztuką bizantyjską identyczna kompozycja, którą nazwiemy symetryczną bądź za A. Waltonem - piramidalną.

W Irlandii, scena ukazująca Trzech Młodzieńców, nie występuje ani w rzemiośle, ani w manuskryptach, jedynie na wielkich kamiennych krzyżach. Na bazie analizy zachowanych do dziś krzyży możemy stwierdzić jej istnienie na 7 krzyżach (il. 11-14): na bazie krzyża z Moone (hr. Kildare), na trzonie krzyża Patryka i Kolumby z Kells (hr. Meath), na głowicy krzyża Wysokiego w Monasterboice (hr. Louth), na trzonie krzyża z Arboe (hr. Tyrone) oraz prawdopodobnie na trzech słabo zachowanych scenach z bazy z Seir Kieran (hr. Offaly), trzonu krzyża z Armagh (hr. Armagh) i trzonu krzyża z Galoon (hr. Fermanagh) ${ }^{16}$. Irlandzki typ ikonograficzny, mimo wielu podobieństw z przykładami bizantyjskimi, jest wyjątkowy ze względu na detale. Oto cechy przedstawień irlandzkich.:

1. Scena posiada frontalną i centralną kompozycję z 3 postaciami i ukazanym powyżej, na osi, większym od nich, aniołem.

2. Skrzydła anioła tworzą nad Młodzieńcami rodzaj namiotu lub groty.

3. W sztuce Irlandii nie pojawia się w ogóle piec: Młodzieńcy nie stoją w ogniu, widoczny jest on jedynie ponad skrzydłami anioła, który całkowicie oddziela go od postaci.

4. Młodzieńcy nie unoszą tak rąk, jak w przedstawieniach rzymskich, afrykańskich czy bizantyjskich, ponieważ ich nie posiadają lub dlatego, że tulą się do siebie.

5. W kilku scenach pojawiają się dwaj mężczyźni dokładający do pieca, a w jednej ze scen dmą oni jednocześnie w trąby.

6. Anioł na wysokim krzyżu z Monasterboice jest kobietą (wyraźnie widoczne są piersi).

Dominującą rolę anioła oraz symetryczną kompozycję posiadają także bizantyjskie przykłady, które pochodzą z manuskryptu z klasztoru na Górze Athos (il. 15) oraz z homilii Grzegorza z Nazjanzu (il. 16). Zarówno w Irlandii, jak na Wschodzie, postać anioła wyznacza oś kompozycji symetrycznej oraz stanowi zwieńczenie i zamknięcie od góry całości. Całe przedstawienie ma charakter frontalny, postaci stoją en face do patrzącego, w sztywnych, zastygłych pozach. Wyizolowany przykład stanowi scena z palestyńskiej miniatury z Sacra Parallela z IX wieku (il. 10), bowiem nawiązuje do przedstawień właściwych dla epok wcześniejszych (kompozycja horyzontalna z postacią Nabuchodonozora) ${ }^{17}$.

${ }^{16}$ Cyt. za: P. Harbison, The High Crosses of Ireland. An Iconographical and Photographic survey, I, Bonn 1992, 225-227; por. też J. Romilly Allen, Early Christian symbolism in Great Britain and Ireland. The High Crosses of Ireland, London 1887, repr. 1992, 213-216; H. Richardson J. Scarry, An Introduction to Irish High Crosses, Dublin 1990, 57, 61, 76-77, 100, 106-107, 131.

17 Sacra Parallela (Florilegia), przypisywana Janowi Damasceńskiemu (PG 95, 1040-1588; PG 96, 9-442), jest kompilacją biblijnych i homiletycznych tekstów, dotyczących życia ascetycznego 
Irlandzkie przykłady, mimo generalnych podobieństw z bizantyjskimi, posiadają szczegóły, które te dwie grupy różnią: mężczyzn dorzucających do ognia, którzy w jednym wypadku dmą jednocześnie w trąby, i anioła pod postacią kobiety. Postać nakładająca do pieca pojawiła się już w IV wieku, we wczesnochrześcijańskiej sztuce Rzymu, jednak w Irlandii, dla symetrii lub względów symbolicznych umieszczono dwóch mężczyzn, po obu stronach pieca. Uczeni irlandzcy interpretują przedstawienia z krzyży celtyckich jako typ Zmartwychwstania (za Ireneuszem i Tertulianem), a piec postrzegają jako typ Kościoła, gdzie ludzie doznają cierpienia w hołdzie Zbawicielowi (Cyryl Aleksandryjski) $^{18}$. F. Henry porównuje irlandzkie sceny z Ukrzyżowaniem i wskazuje na paralelę dwóch symetrycznie stojących postaci, dorzucających do pieca, do stojących przy krzyżu Longinusa i Stefatona ${ }^{19}$. Dlaczego na krzyżu w Monasterboice anioł jest kobietą pozostanie problemem nierozwiązanym bowiem nie posiada plastycznych paraleli, a wyjaśnienie znajduje się prawdopodobnie w irlandzkich apokryfach.

Szukając źródeł inspiracji dla irlandzkich przedstawień uczeni wskazują na malowidła ścienne w Santa Maria Antiqua w Rzymie, datowane na VII wiek, ze względu na fakt, że inne przedstawienia tego kościoła mają elementy wspólne ze sztuką krzyży irlandzkich. Jednak zły stan zachowania sceny z młodziankami nie pozwala skonfrontować tej tezy ${ }^{20}$. Drugim wskazywanym źródłem inspiracji są miniatury z homilii Grzegorza z Nazjanzu (Ms.gr. 510). Kopia homilii została wydana w Konstantynopolu dla cesarza Bazylego I i jego rodziny, jako prezent od Patriarchy Focjusza $(877-886)^{21}$. Manuskrypt ten powstał w latach 879-882 i dziś znajduje się w Bibliotece Narodowej w Paryżu, a znany jest jako Codex Graecus $510^{22}$. Jako jedna z trzech najwcześniejszych kopii homilii Grzegorza, uznany został za najbardziej kompleksowy i najlepiej opracowany ilustrowany manuskrypt, jaki powstał w Bizancjum ${ }^{23}$. Kodeks zawiera 66 dekorowanych stron, które jak podkreśla L. Brubaker, nie są prostą ilustracją wydarzeń biblijnych, lecz ilustracją szczególnego komentarza

i moralnego, por. K. Weitzmann, Sacra Parallela Parissinus Graecus 923, Princeton 1979; H.L. Kessler, The miniatures of the Sacra Parallela: Parisinus Graecus 923, „Speculum” 56 (1981) 208-220.

${ }^{18}$ Cyt za: Romilly Allen, Early Christian symbolism in Great Britain and Ireland, s. 214.

19 Por. Henry, Irish art during the Viking Invasions, 150.

20 Por. J. Wilpert, Die Römischen Mosaiken und Malereien der Bauten, tab. 146; P. Harbison (The High Crosses of Ireland, s. 226) sugeruje, że schemat podobny do irlandzkiego mógł występować w Santa Maria Antiqua w Rzymie, a wspólny prototyp mógł, jego zdaniem, powstać ok. VIII-IX wieku w Rzymie.

21 Wspaniałą analizę manuskryptu dokonał L. Brubaker w: Vision and Meaning in Ninthcentury Byzantion. Image as Exegesis in the Homilies of Gregory of Nazianzus, Cambridge 1999.

22 Por. Brubeker, Vision and meaning, s. XVII; I. Spatharakis, The Portraits and the date of the Codex Par.Gr. 510, „Cahiers Archéologiques” 23 (1974) 97-105.

23 Por. Brubeker, Vision and meaning, s. 13. 
Grzegorza, który ma charakter wizyjny, co rodzi dzisiaj daleko idące problemy metodologiczne w interpretacji przedstawień malarskich ${ }^{24}$. Kompozycja sceny z Trzema Hebrajczykami, pochodząca z homilii Grzegorza, jest rzeczywiście zbliżona do wszystkich irlandzkich przykładów, a identyczna z tymi z Moone i Arboe (il. 11, 13).

Typ kompozycji symetrycznej z uwypukloną rolą anioła był bardzo popularny na bizantyjskim Wschodzie i występował także w innych scenach. Na plakietce z kości słoniowej, wykonanej w Syrii w VII wieku (Victoria and Albert Museum w Londynie), pierwotnie zdobiącej prawdopodobnie drewniane drzwi prowadzące do kościoła, widzimy jak anioł swymi skrzydłami łączy dwie postaci - św. Piotra i św. Pawła przedzielonych pulpitem ${ }^{25}$. W średniowieczu, w Biblia Pauperum, wydarzenie męczeństwa Trzech Hebrajczyków utożsamiano z „Przemienieniem” i „Wizytą Aniołów u Abrahama” ${ }^{26}$, co znalazło odbicie w podobnej kompozycji tych scen w sztuce. Taki typ kompozycji przetrwał także w ikonowej sztuce rosyjskiej, w okresie od średniowiecza po czasy nowożytne (il. 17).

Uczeni nie próbują interpretować faktu zmieniającej się ikonografii i kompozycji sceny ukazującej Trzech Hebrajczyków w piecu ognistym. Fakt ten uznaje się raczej jako wynik odmiennych tradycji artystycznych, niż odbicie odmiennych sposobów postrzegania historii zaczerpniętej z Księgi Daniela. Na podstawie wielu lat pracy nad ikonografią i symboliką sztuki I tysiąclecia muszę stwierdzić, że kompozycja przedstawień ma zawsze kluczowe znaczenia dla wyrażonych w obrazie treści - wyznacza kierunek interpretacji, sugerowany aspekt i ukryte treści. Zbyt często jest jednak uważany za wynik jedynie często przypadkowych - inspiracji czysto plastycznych. Nie bez racji byłoby stwierdzenie, że typ rzymski przedstawień z Trzema Hebrajczykami ma charakter opowiadający, fabularny i ciągły, czemu sprzyja układ horyzontalny sceny, natomiast typ kompozycji bizantyjsko-irlandzkiej, wydaje się mieć charakter symboliczny, bowiem sztywny schemat kompozycji zawsze w dziejach sztuki nosił cechę znaku, symbolu czy alegorii. Pewnym wydaje się fakt, że ten typ kompozycji nie wynika z prostej ilustracji historii biblijnej, pytamy więc, co ta scena symbolizuje? Jaki paradygmat zawarto w bizantyjskich i irlandzkich scenach? Odpowiedź na te pytania, to temat na odrębną rozprawę, która wymaga analizy źródeł pisanych i świadectw religijnych, a także analizy zjawisk historycznych, właściwych dla epoki, w której ten rodzaj kompozycji powstał, czyli IX wieku. Wydaje się jednak, że u podłoża bizantyjsko-irlandzkiego typu przedstawienia leży odradzający się w IX wieku neoplatonizm,

${ }^{24}$ Por. tamże, s. XVII.

25 Por. Age of Spirituality. Late antique and Early Christian Art. Third to seventh century. Catalogue of the exhibition at the Metropolitan Museum of Art (19 XI 1977 through 12 II 1978), ed. K. Weitzmann, New York 1979, 546.

26 Por. Romilly Allen, Early Christian symbolism in Great Britain and Ireland, s. 216. 
a także powrót do tradycji i mentalności perskiej poprzez powracającą w tym czasie starą literaturę, a z nią do niezmiennej od sztuki Luristanu (III tys. prz. Chr.) kompozycji symetrycznej, frontalnej i hieratycznej przedstawień.

IRELAND AND BYZANTIUM.

THE ICONOGRAPHY OF THE TREE HEBREW CHILDREN IN THE FIERY FURNACE OF CELTIC CROSSES

The article presents illustrations of Dn 3, 19-24 in first millennial art. The author propos tree types of iconography and compositions this biblical history: Roman, Coptic-Nubian and Irish-Byzantine. The Roman type has character of illustrations instead two others from Christian East are symbolical. 


\section{ILUSTRACJE}

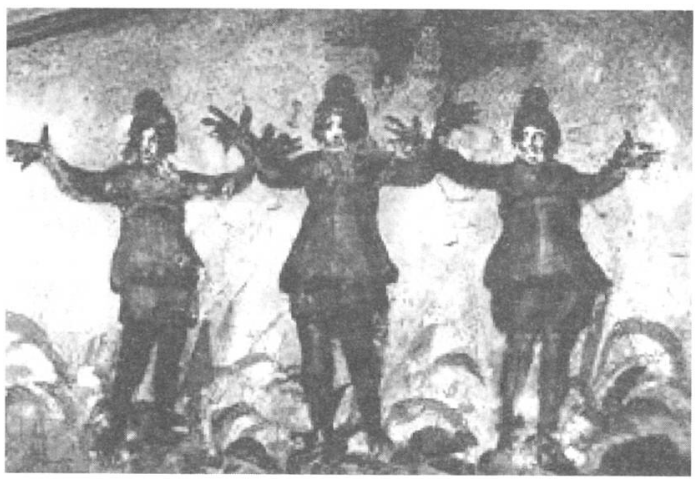

Il. 1. Katakumba Pryscylli, Cubiculum Velatio, według: A Mulhern, L'orante. Vie et mort d'une image, ,Les dossiers de l'archéologie” 18 (1976) 46.

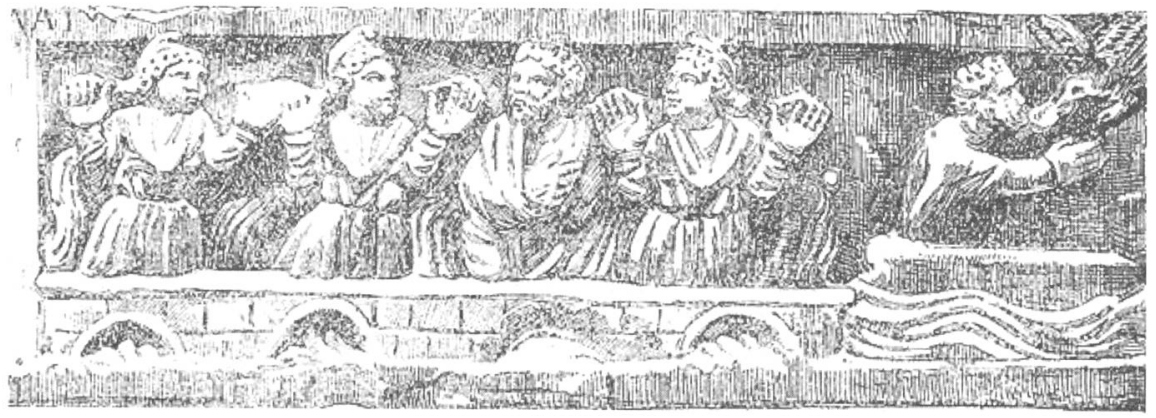

Il. 2. Przerys sarkofagu z Watykanu, według: DACL VI/2, il. 5609.

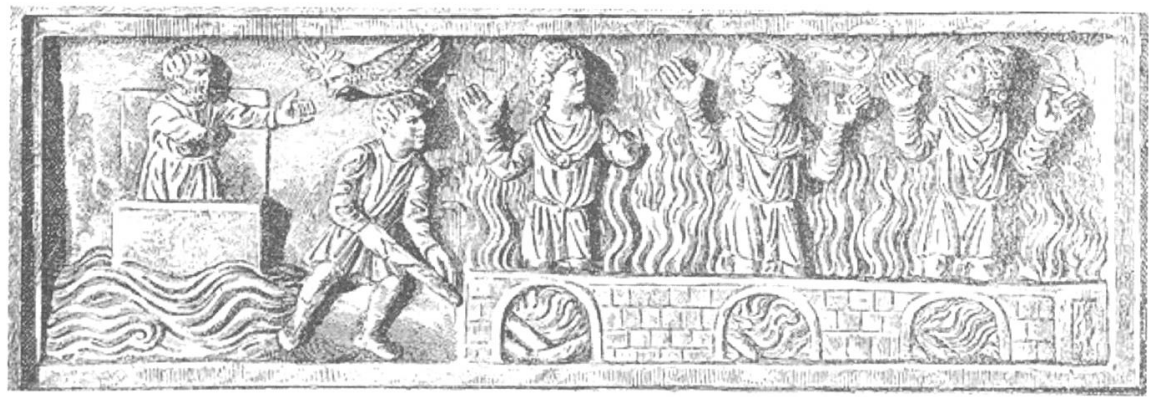

Il. 3. Przerys sarkofagu z Watykanu, według: DACL VI/2, il. 5610. 


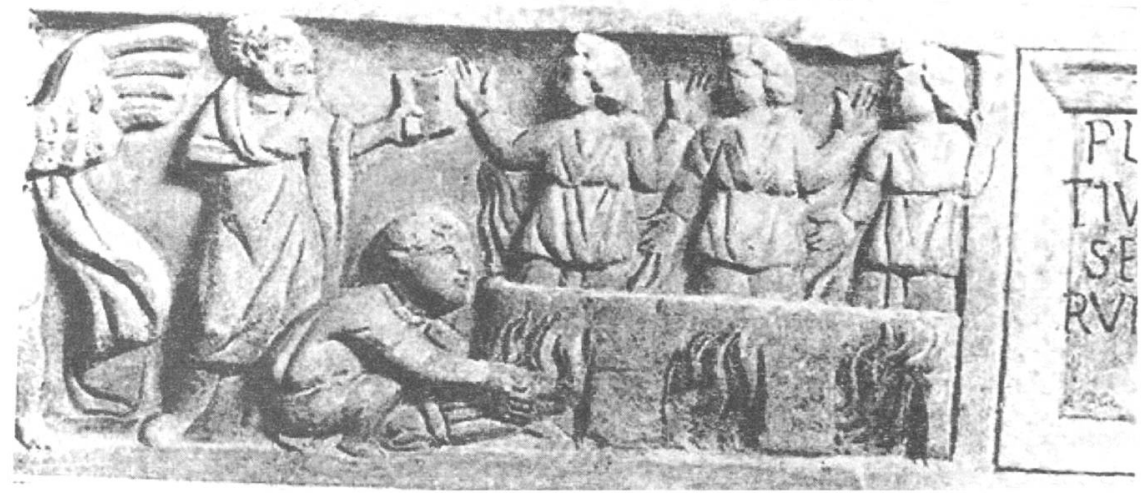

Il. 4. Sarkofag z Watykanu, według: C. Carletti, I tre giovani ebrei di Babilonia nell'arte cristiana antica, Brescia 1975, fig. 12.

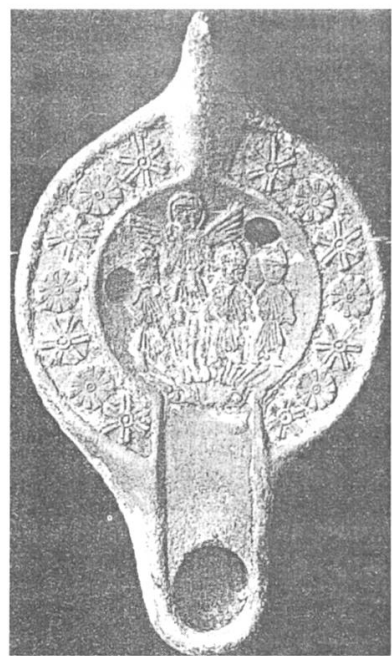

Il. 5. Lampka oliwna (chrześcijańska bądź żydowska) z Kartaginy, IV wiek, według: V.A. Klagsbald, Clay lamps with biblical scenes, ,Journal of Jewish Art” 3-4 (1976/77) fig. 7.

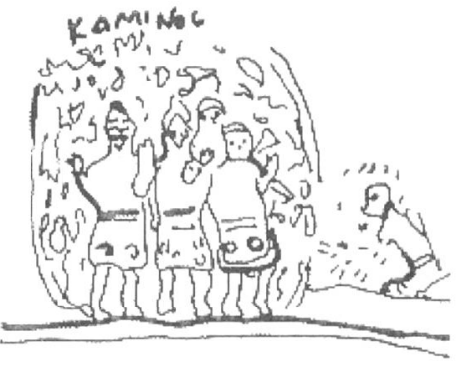

Il. 6. Mauzoleum w el-Bagawat (Egipt), IV/V wiek, według: A. Fakhry, The Necropolis of el-Bagawat in Kharga Oazis, Cairo 1951, fig. 42 . 


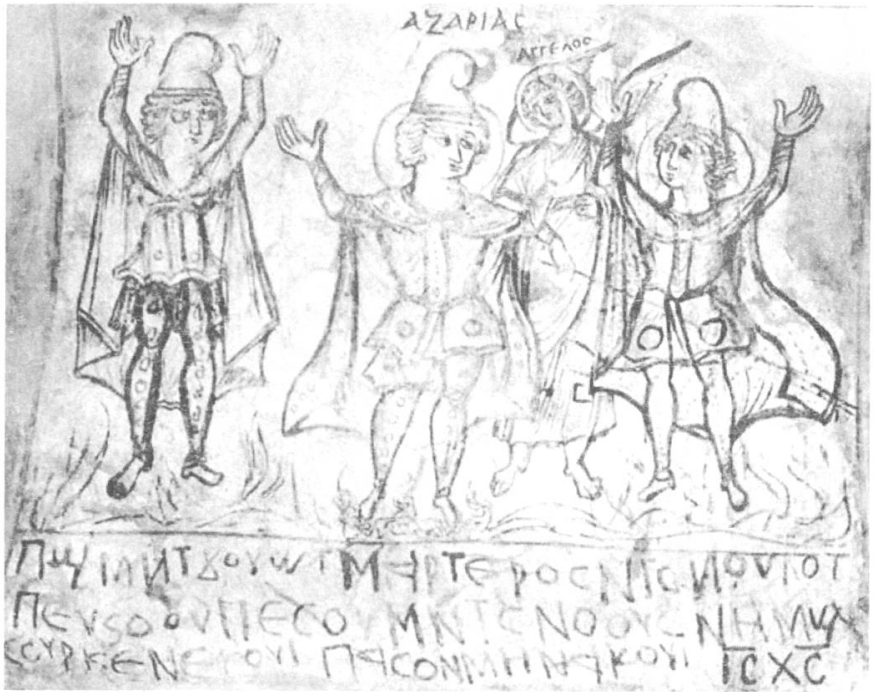

Il. 7. Trzej Hebrajczycy w piecu ognistym, fragment malowideł z koptyjskiego klasztoru w Wadi Sarga, Egipt, VI wiek, według: K. Wessel, L'art copte. L'art antique de la Basse-époque en Égypte, Bruxelles 1964, 158, il. 101.

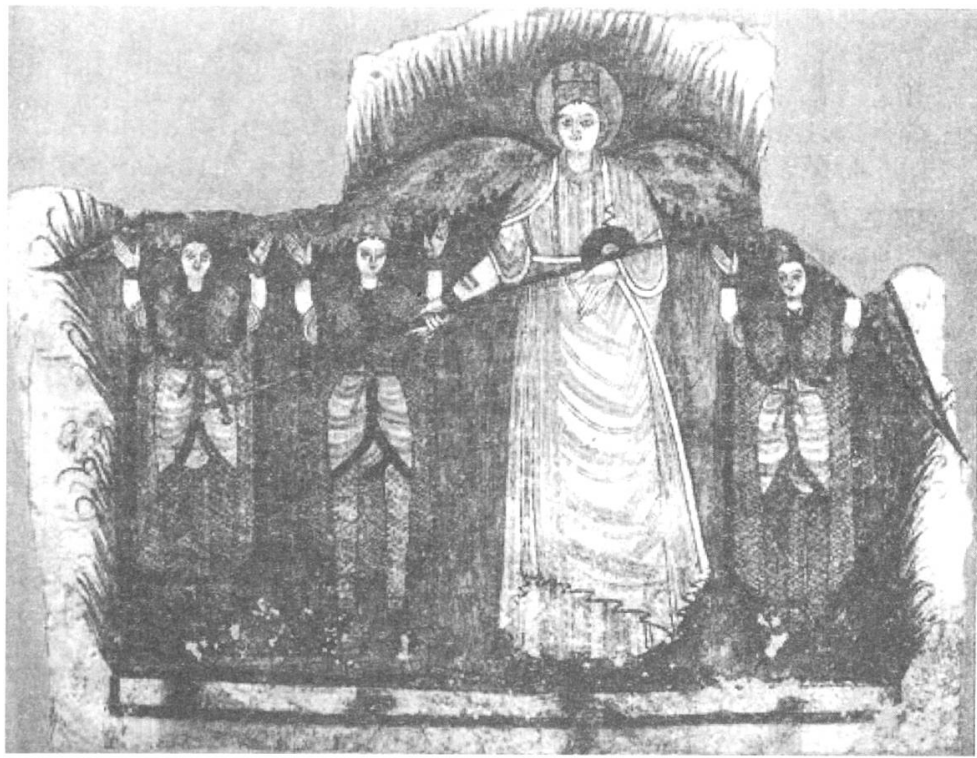

II. 8. Katedra w Faras (Nubia), według: M. Łaptaś - S. Jakobielski, ,, Unknown” mural of the three youths in a fiery furnace from the Faras cathedral, w: Ars Greca, Ars Latina. red. W. Bałus - W. Ceran - O. Jurewicz i inni, Kraków 2001, 85. 


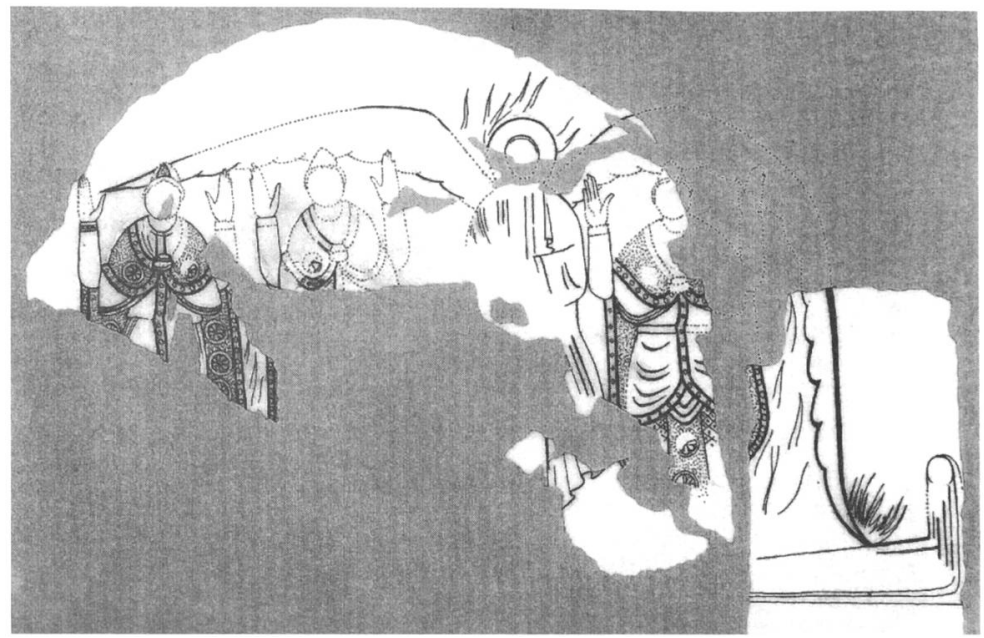

Il. 9. Katedra w Faras (Nubia), według M. Łaptaś - S. Jakobielski, „Unknown” mural of the three youths in a fiery furnace from the Faras cathedral, s. 84 (przerys malowidła W. Chmiel).

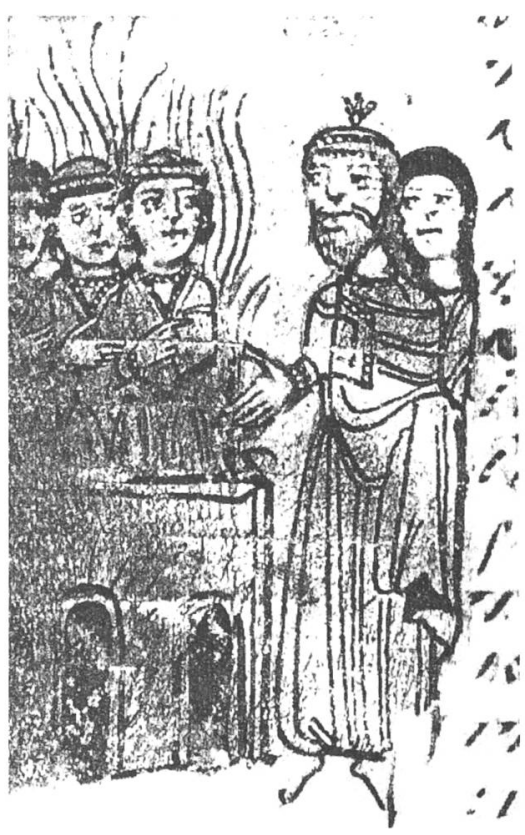

Il. 10. Sacra Parallela Jana Damasceńskiego Ms.gr. 923, datowane na IX wiek, dziś w Muzeum Narodowym w Paryżu, fol. 373, według: P. Harrison, The High Crosses of Ireland. An Iconographical and Photographic survey, III, Bonn 1992, 762. 


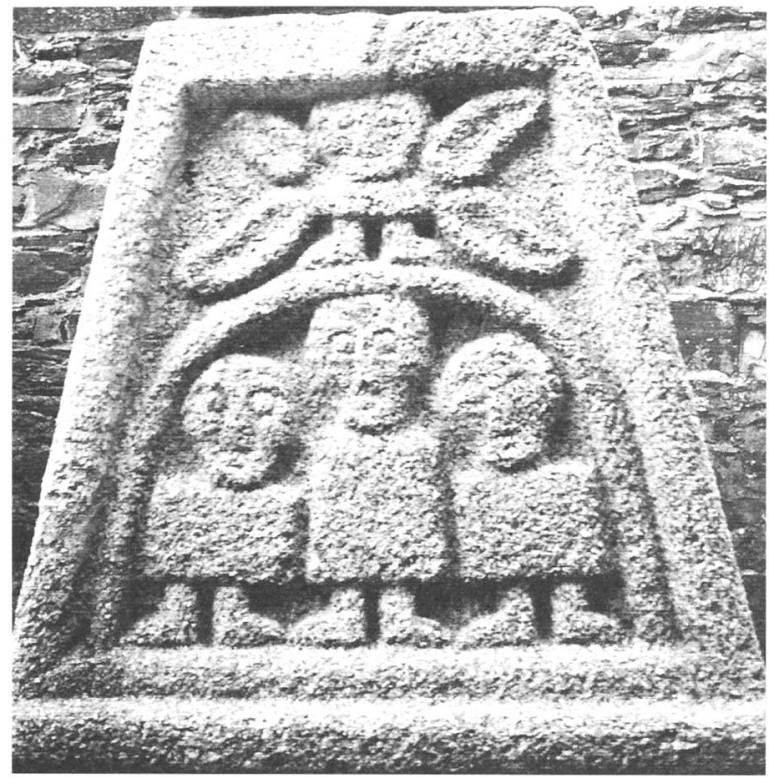

Il. 11. Własność prywatna autorki.

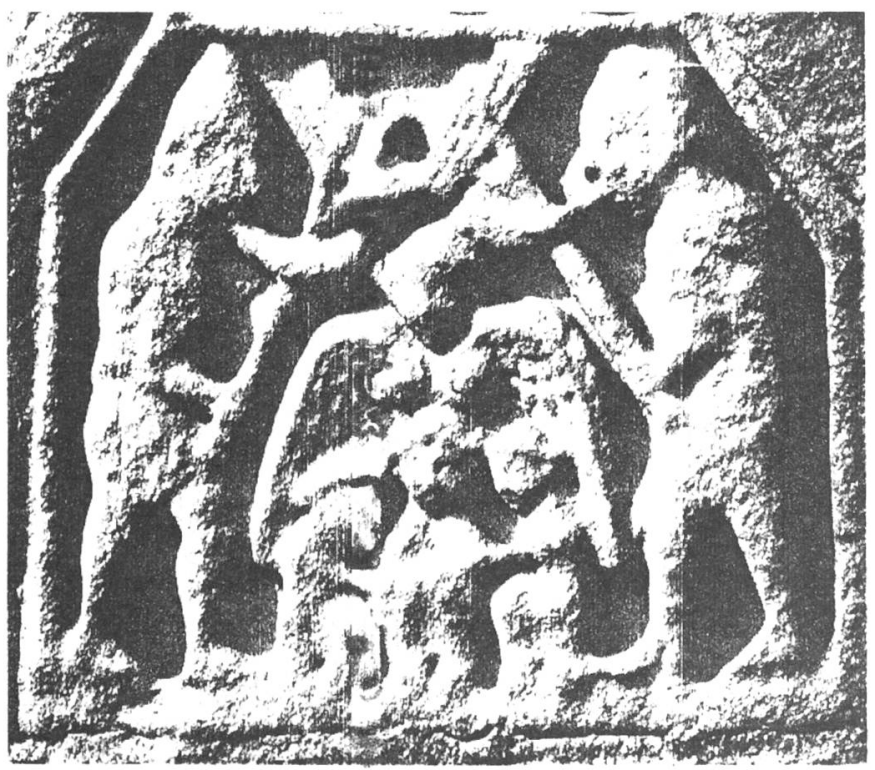

Il. 12. Krzyż Wysoki z Monasterboice (hr. Lough), według: P. Harbison, The High Crosses of Ireland. An Iconographical and Photographic survey, Bonn 1992, vol. 3, fig. 756. 
74

RYSZARDA BULAS

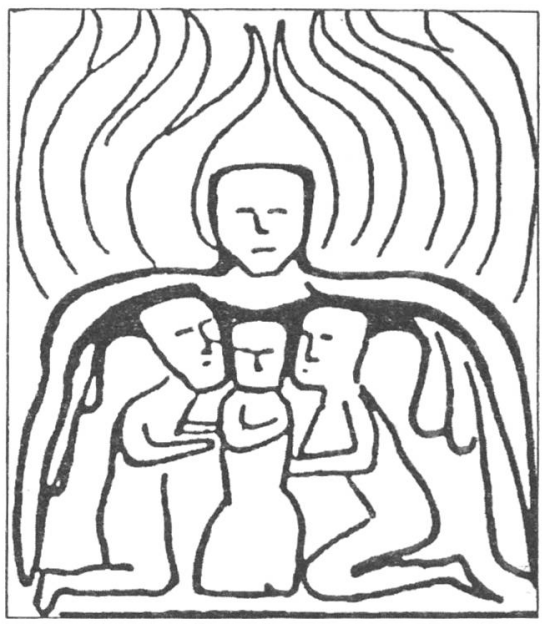

Il. 13. Krzyż z Arboe (hr. Tyron) według: F. Henry, La sculpture irlandaise pendant les douze prèmiers siècles de l'ère chrétienne, Paris 1933, fig. 120 (przerys).

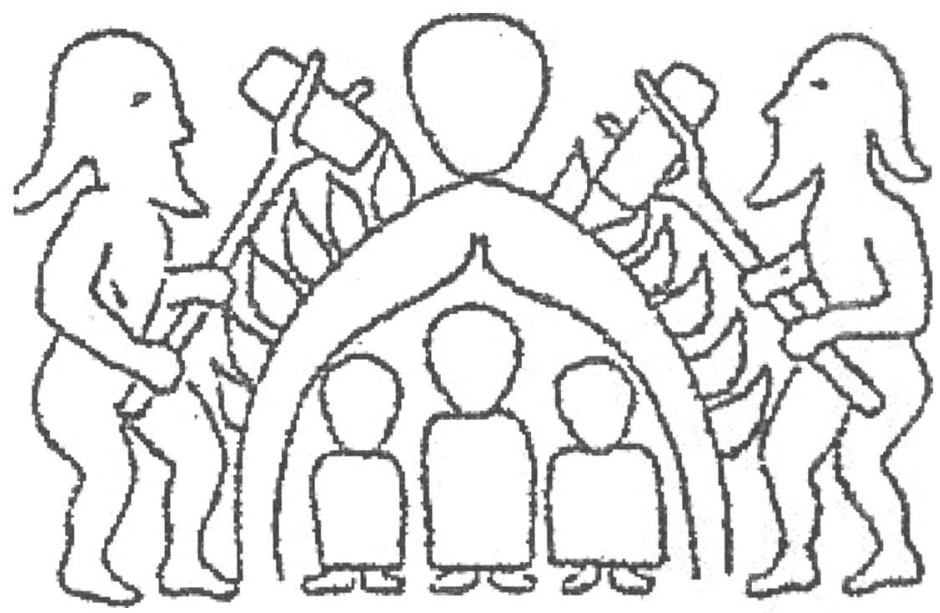

Il. 14. Krzyż św. Patryka i Kolumby z Kells (hr. Meath) według: J. Romilly Allen, Early Christian symbolism in Great Britain and Ireland. The High Crosses of Ireland, London 1887, repr. 1992, 214, fig. 68 (przerys). 


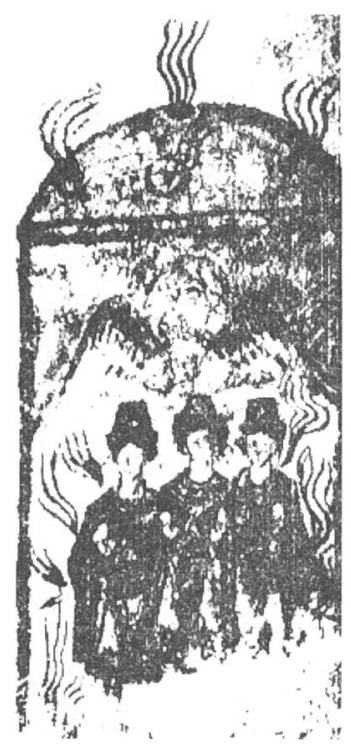

Il. 15. Manuskrypt nr 61 z klasztoru Pantokratora na Górze Athos, datowany na IX wiek, fol. 222, według: P. Harbison, The High Crosses of Ireland. An Iconographical and Photographic survey, Bonn 1992, vol. 3, fig. 760.

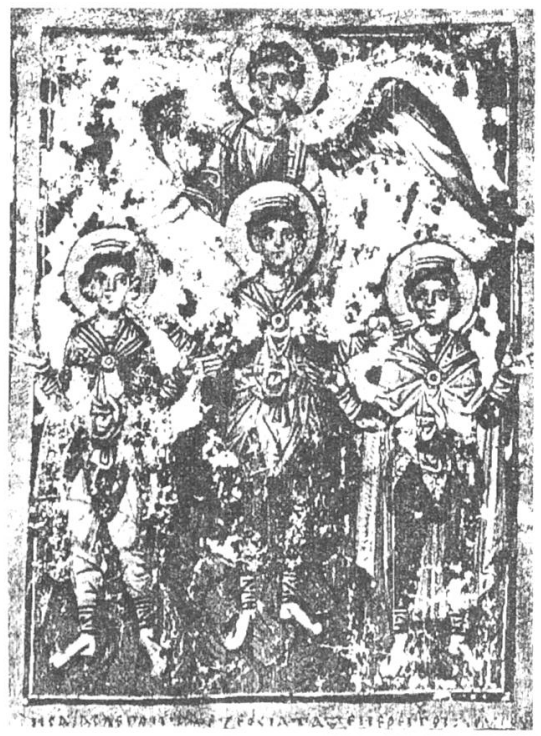

Il. 16. Ms. Gr. 510, Homilia Grzegorza z Nazjanzu IX w., według: P. Harbison, The High Crosses of Ireland. An Iconographical and Photographic survey, Bonn 1992, vol. 3, fig. 755. 


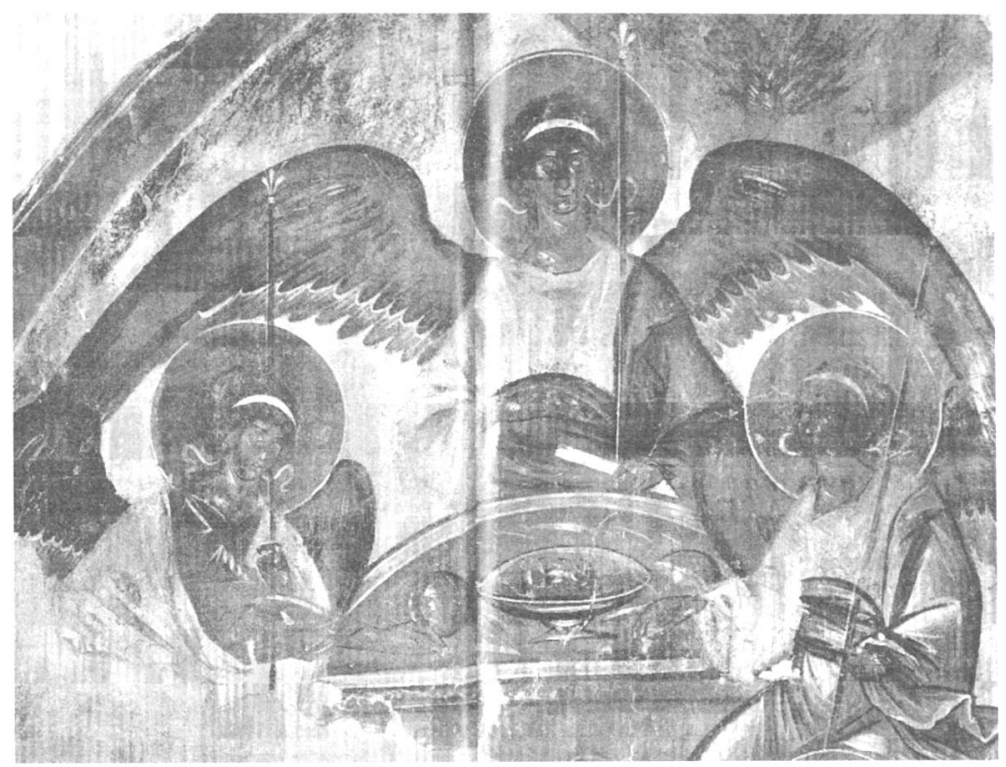

Il. 17. Scena Przemienienia, fresk, Petersburg, kościół Naszego Zbawcy, XIV wiek, według: Novgorod. Art. Treasures and Architectural Monuments $11^{\text {th }}-18^{\text {th }}$, ed. V. Gormin L. Yarosh, tłum z ros. na ang. L. Sorokina - C. Justice, Leningrad 1984, il. 76. 